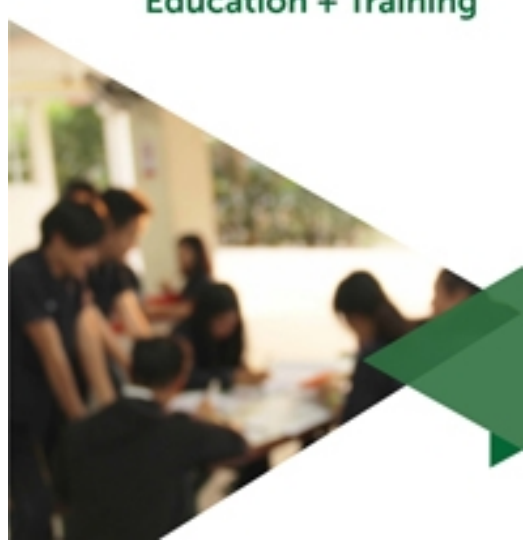

Understanding the Trajectory of the Academic Progress of International Students in the UK

\begin{tabular}{|r|l|}
\hline Journal: & Education + Training \\
\hline Manuscript ID & ET-08-2018-0177.R3 \\
\hline Manuscript Type: & Research Paper \\
\hline Keywords: & $\begin{array}{l}\text { Higher Education, Learning and Development, International Students, } \\
\text { Focus Group }\end{array}$ \\
\hline \multicolumn{2}{|l}{} \\
\hline
\end{tabular}




\title{
Understanding the Trajectory of the Academic Progress of International Students in the UK
}

\begin{abstract}
Purpose - The UK is a popular educational hub for international students from different parts of the world. These students often face different transitional challenges, which have a significant impact on the success or failure of their studies. This study systematically investigates the issues and challenges confronting international students in UK in their efforts to acquire academic knowledge and achieve personal development.
\end{abstract}

Design/Methodology/Approach - A total of 104 UK-based international students in five higher education institutes in London from 25 countries participated in this study. The study was undertaken qualitatively through 21 semi-structured and 13 focus group interviews.

Findings - The findings reveal that the process of transitional adjustment is affected by various issues, all of which determine the duration of the students' involvement in each stage of the transitional process. International students in the UK experience language/accent-related difficulties; impaired communication; and a difficult adjustment to the British education system and culture.

Research Limitations/Implications - The extent to which the findings of this research can be generalised is constrained by the limited scope of the research.

Practical Implications - In choosing to study in the UK, international students primarily seek to obtain a qualification, other life experiences, and cultural assimilation. The students' parents, institutions, and the UK authorities (such as the Department of Education) have an important role in ensuring that the students achieve success. While the roles of parents and the UK authorities are not the focus of this article, their supportive roles certainly allow students to complete the different stages of the process of transitional adjustment quickly and smoothly.

Originality/Value - The study offers valuable insight into understanding the challenges facing international students in acquiring knowledge in a foreign land. The article contributes to the pedagogic literature on this topic by proposing a three-stage scaffolding model.

Keywords: Learning, development, UK, higher education, international students, focus group 


\section{Introduction}

Global higher education (HE) is attractive, and the need for the cross-cultural movement of learners in search of the highest quality HE will remain important for a long time. The UK education system is considered to be one of the best in the world (Lomer et al., 2016), hence the regular influx of international students from different parts of the world, who have turned the UK into a popular and important educational hub (see Figure 1). The international student often experiences the phenomenon of border crossing as they change from one cultural milieu to another, making the necessary adjustments to achieve success in the new domain.

These students must adjust to their new host cultures; however, they also bring with them the cultural values of their formative years. Although their main and ultimate consideration is often educational and qualifying attainment, the required sociocultural adjustments transcend education. The lines between the definitions of education, culture, and values at the point of the transition are blurred and often indistinguishable as they all have a significant impact on the success or failure of their studies.

This article investigates the issues and challenges confronting international students in the UK in their efforts to acquire academic knowledge and personal development. We adopt the combined definition of an 'international student' as a student who is enrolled in a UK HE institution (HEI) undertaking an undergraduate or postgraduate course and is not a UK citizen, refugee, immigrant, member of an European Union (EU) state, or permanent UK resident (Al-Quhen, 2012; Lillyman and Bennett, 2014).

According to the UK Council for International Student Affairs (UKCISA, 2017), 80\% of all students who studied in HE in the UK in 2015/2016 were from the UK (home students), $6 \%$ were from other EU countries, and 14\% were from the rest of the world. Cumulatively, a total of 438,010 international students studied in the UK in that academic year (UKCISA, 2017), a significant increase compared with the previous academic year. While international students accounted for between $13.4 \%$ and $15 \%$ of the total UK HEIs' population, among which the biggest share $(12 \%)$ came from China (King et al., 2010). They also contribute one-third of the total income of UK universities (Brown and Holloway, 2008).

Lillyman and Bennett (2014) identified several other benefits of international students, for the host country as well as for the students. Furthermore, because many sources tend mainly to review the negative perspectives of international students, positive experiences are often lost within the literature. Their presence in the UK contributes considerably to the academic, social, and financial health of most HEIs and, indeed, the larger economy (Largo, 2003).

Ultimately, the intention of the UK education system is to help students (regardless of their origin) acquire knowledge and expertise and to become progressively 
independent during and after their academic adventures in the UK. In order to achieve these lofty objectives, students are required to be engaged in both academic and nonacademic activities (Astin, 1993; Ma and Wen, 2018). These activities are educationally purposeful, and they include events inside and outside of the classroom (Pascarella and Terenzini, 1991).

Studies that have examined the adjustment process of international students have focused on both their academic performance and their social and emotional adjustment. The presence of a significant overlap between these processes means that the studies do not distinguish between the two spheres of the students' lives in empirical investigations. From an academic perspective, international students are characterised by their high intellectual ability and high level of motivation which, with appropriate mentoring and support, can assist them in overcoming the challenges associated with academic achievement (Boylan, 2002; Idris et al., 2019).

They are also more engaged than home students in their studies (Andrade, 2006). Morrison et al. (2005) noted that there is no evidence that this group of students performs worse than home students. The extant studies that have focused on the academic performance of international students have found that the perceived importance of learning success to their family, their English writing ability, and social communication with their compatriots are significant predictors of academic achievement. It has also been reported that Chinese students specifically have a less active learning strategy than others, and that there is no evidence to indicate that this negatively affects their academic achievement (Li et al., 2010).

Therefore, there is a lack of conclusive evidence on the range of issues and challenges that international students face and the appropriate policy responses by HEIs and various support units for international students. In the light of the recent Brexit vote, the ongoing Brexit negotiations, and the widespread anti-immigration tone among the British population, a study providing empirical evidence regarding international students is timely and valuable.

This article, therefore, is intended to stimulate further discussion and debate on the potential issues and challenges confronting international students in the UK in their efforts to acquire academic knowledge and personal development. It also proposes solutions that could make their learning and development much easier and more successful. An empirical study of this nature has hitherto been rare in the literature, thus making this study timely and essential.

\section{Learning and Cross-Cultural Issues}

One of the lofty objectives of HE is to develop students and make them complete human beings (Braskamp et al., 2009). Learning and development in HE is not only concerned with the academic and intellectual development of students, but also their intercultural competency/global learning and their moral, social, and physical 
development (Association of American Colleges and Universities, 2007; Musil, 2006; Yarosha et al., 2018; Cao et al., 2018). It has been argued that this holistic focus is the added value of HE, particularly in the UK (Braskamp et al., 2009). Learning and development emphasises both the internal and external growth and development of students (Deardorff, 2006; Deardorff and Arasaratnam-Smith, 2017). Students learn in diverse ways, and there is no one-size-fits--all learning approach.

However, learning patterns in HE across cultures are different (Smith and Paracka, 2018). A meta-analysis of the inventory of learning styles (ILSs) of two Asian countries (Sri Lanka and Indonesia) and one European country (the Netherlands) revealed that culture plays a significant role in the students' learning and metacognitive strategies and learning orientations (Marambe et al., 2012). The growth in student mobility means that a record number of students are traveling abroad for studies (especially the UK, see Figure 1), making the study of cross-cultural issues highly relevant.

The experience of studying abroad is gratifying and enriching (Marambe et al., 2012), but adaption to a new culture is challenging (Kemmis and Edwards-Groves, 2017). Most of the time, learning patterns, approaches, regulations, strategies, conceptions, and orientations can conflict with the method of learning that is in practice in universities abroad. For example, Wierstra et al. (2003) found huge differences in educational cultures between northern and southern Europe, as reported by international exchange students. Similarly, Biemans and Van Mil (2008) in their study of Dutch and Chinese students found that the Chinese students were disappointed in the Dutch learning culture, which stands at variance to what they are used to. These studies underline the importance of cross-cultural transition in the trajectory of the learning and development of international students.

Typically, learning is symmetrically presented in the dualism of either studentcentred learning or teacher-centred learning ( $\mathrm{O}^{\prime} \mathrm{Neil}$ and McMahon, 2005). The teacher-centred approach is based on the model of an active teacher and a passive student (Mascolo, 2009). This approach is believed to involve lectures as a primary means of communication in the classroom. Conversely, student-centred learning is a pedagogical learning approach that emphasises a shift in focus and power from the teacher to the learner (Barr and Tagg, 1995). Student-centred leaning emphasises that knowledge is constructed by students and presents the teacher as a mere facilitator of learning rather than a presenter of information (Kember, 1997). The tenets of this approach align with the paradigm of andragogy, which describes learners as selfdirected and as resources for their own learning and that of others (Knowles, 1980; 1989).

Student-centred learning appears to be reflective of $21^{\text {st }}$ century society, which presents people with the opportunity to make choices ( $\mathrm{O}^{\prime} \mathrm{Neil}$ and McMahon, 2005). This approach has, in most cases, been found to produce higher quality learning than 
the traditional teacher-centred approach (Sharan, 1990), and it is archetypal of the western/developed world's learning approach.

Many countries in Asia (China, Malaysia, Singapore, Vietnam, Japan, Thailand, Hong Kong, and Korea) have a Confucian heritage culture, which underpins and impacts considerably many aspects of the society including education and schooling systems. However, the importation of student-centred approach into these cultures without adequate consideration given to philosophical and cultural differences impede students' learning and developmental proficiencies (Thanh, 2014).

The diverse nature of students coming to study in the UK universities echoes the enormity of the challenges of cross-cultural learning in HE (Wettea and Furneaux, 2018). The task of addressing language differences, educational and pedagogical differences, reasoning patterns differences, high and low, and social contextual differences is by no means an easy one (Edmundson, 2007).

Another cross-cultural challenge is getting students from different cultural background to work together. For example, in the UK, Harrison and Peacock (2010) found that many domestic students felt negative about learning with international students. Similarly, Moore and Hampton (2015) found that many students prefer to work with those from their cultural background. Furthermore, Singaram et al. (2011) found occurrences of self-segregation by cultural background between students in collaborative tutorials in a problem-based learning environment.

Intercultural communication is crucial to individual development and success in an intercultural and pluralistic society (Bennett and Bennett 2004; Ploner, 2018). Due to the fast-growing phenomenon of the internationalisation of HE in UK HE (Quan et al., 2016), it is worthwhile to investigate the trajectory of the academic progress of international students in the UK. Questions, however, remain. What do international students think about the model of student learning and development in the UK? To what extent are these students receptive and consider the student-centred approach, highly favoured in the UK, to be beneficial?

\section{Insert Figure 1 about here}

\section{International Students and the Process of Transitional Adjustment}

The number of international students coming to the UK obtain degrees is growing exponentially (Higher Education Statistical Agency, 2018), with England being the preferred destination for many international students (see Figure 1). International students are a group of people from different countries who bring a diversity of cultures and educational backgrounds from their home countries to acquire academic knowledge and degrees in another country (Bevis and Lucas, 2007).

UK universities are reputable for their internationally recognised qualifications (British Council Report 2014), and they are the second most popular destinations in 
the world for international students outside of the US (UK Council for International Student Affair [UKCISA], 2015). However, the excitement of studying in the UK is often shattered by the challenges that naturally arise in a new country/culture and academic environment.

Ejiofor (2010) highlighted the issue of collaborative and participative learning, which many international students often find challenging. Eringa and Huei-Ling (2009) argue that the academic and social integration of international students in HE is not only challenging, but also impacts their academic progress. This means that there is a negative relationship between academic performance and social adjustment (Mannan, 2007). Of great concern is that $35 \%$ of international students in the UK have been found to have developed mental issues due to the various challenges confronting them in their new environment (Atack, 2018). According to UKCISA (2015), academic transition remains one of the most critical challenges facing international students in the UK.

The gap in the literature on the topic of international students' transition to their host culture has been acknowledged by Quan et al. (2016) and Nada and Araujo (2017). However, empirical studies that look beyond the transitional process of a specific cohort (specifically Chinese students) are somewhat rare. The transitional process needs to be understood in the wider context of globalisation. This is because globalisation has proliferated cross-border collaborative education programmes (Heffernan et al., 2010; Nada and Araujo, 2017), a phenomenon that keeps the UK border open to thousands of students from across the globe every year (Tang and Nollent, 2007).

Furthermore, researchers have argued that studies that involve students from different cultures/countries are needed considering the dynamic and complex crosscultural transitions (Major, 2005; Zhou et al., 2008). A smooth transition to HE is crucial to students' learning and development (Pike and Harrison, 2011). While students often find the prospect of an academic sojourn in a foreign country exciting, the experience is usually constrained by uncertainty and disorientation in terms of adapting to the new culture(s) (Hellstén, 2002). Furthermore, many students find studying abroad and learning across different cultures difficult (Sluss and Ashforth, 2007).

It is, however, important to note that the process of adjustment in adapting to a new culture is not singular; rather, it develops in stages ( $\mathrm{Wu}$ and Hammond, 2011). A tranquil transition is crucial for students' effective academic performance and selfdevelopment (Pike and Harrison, 2011). Existing models acknowledge that crosscultural transition is successive (Brown and Holloway, 2008).

Research is increasingly focusing on the issue of the academic adjustment of both international learners and teachers (Wang and Byram, 2011). The requirements of academic adjustment and the concept of learning vary across the world and the 
argument and cultural justification for holding a particular position may equally vary (Nada and Araujo, 2017; Ploner, 2018). However, it has been suggested that British universities should adopt a culturally responsive pedagogy to accommodate international students who come from multiple backgrounds with different learning norms (Wang and Byram, 2011).

The idea that international students should view overseas study as an opportunity to experience new ways of learning is debatable. Biggs (2003) suggested that we should perhaps focus on the similarities between the education systems rather than the differences to bring out the best learning opportunities for students. Specifically, with respect to Chinese students, Wang and Byram (2011) argued that the evidence shows that they may initially be teacher-dependent, deferential to authority, lacking criticalthinking skills, and dependent on memorisation. However, they are aware of these challenges and can and do change.

\section{Concept Model}

Based on the present study's findings, which drawn on students' experiences and previous studies (Brown and Holloway, 2008; Oberg, 1960; Torbiorn, 1994), this study identifies an empirical-based transitional stage model. This model projects students into new social and academic contexts. It builds on and extends the existing work on the contextualisation of students' experiences and perceptions. The proposed 'threestage' scaffolding model consists of (i) the stormy stage, (ii) the acclimatisation stage, and (iii) the functioning stage.

\section{Insert Figure 2 about here}

Consistent with Borrett and Zysk's (2007) research, which found that international students are confronted with a range of challenges in their first study period in a new country, the current study's model proposes that international students struggle to transit to their new environment in the first stage. In the stormy stage, international students struggle to weather the storm of the new academic and social climate. They are exposed to a social and academic climate that is different to what they are used to in their native culture (Lamberton and Ashton-Hay, 2015; Shaheen, 2016).

There are two categories of students at this stage: (a) those who find both or either of the social and academic climates too difficult to weather and (b) those who quickly understand the new climates and get on well with them. Many students struggle at this stage, and this struggle often has a negative effect on their learning and development. During the acclimatisation stage, the students have, to a large extent, now come to terms with the fact that the social and academic climate is different to what they are used to in their native culture. They are now learning and getting used to the new climate. 
Tinto (1987) described this phase as a stage in which international students let go of the ways and behaviour of the past and learn new methods that are suitable to the new environment. Not all students make it to this stage from the stormy stage. Students who are unable to make it to the acclimatisation stage due to the difficulties in terms of dealing with apparent challenges of the storming stage either leave university or retake the first semester. This depends on their academic performance and ability to cope. All students should aim to reach the functioning stage. The students should have now weathered the storms, be acclimatised to the new climate, be functioning, and be able to cope as well as their counterpart British students. Mushibwe (2009) argued that this a stage in which international students are stable and are well integrated into the new system/climate. For example, international students on masters' or undergraduate programme should aim to reach the functioning stage at about eight weeks into the programme. This will enhance their learning and academic success.

Ryan (2011) made a strong argument about the problematisation of international students. She argued that western academics need to move beyond this problematisation and begin to see international students as a source of internationalisation for universities: 'in truly internationalised and transcultural learning environments, everyone is "international," and global knowledge and skills become available to all' (p. 644). With an increasing number of international students choosing other European destinations (the most popular choice being The Netherlands, Germany, Austria, France, Spain, and Italy) where many universities provide studies in English and due to the threats associated with the UK's exit from the EU, it is only a matter of time before British universities begin to feel the pressure of a lower level of recruitment students.

The UK Higher Education Academy's Teaching International Students (TIS) project aims to address this challenge (Ryan, 2011). Recently, it has been said that internationalisation is a much broader project than the narrow prism of international students (Jones, 2009). It is more about providing an international learning experience beyond exporting education so that global citizens who will commence and continue their careers with enthusiasm in all parts of the world are created (Healey, 2017).

For example, the notion of critical thinking and criticality in writing is often taken as the norm in HE in the West. Most international students are unlikely to have a full understanding or appreciation of this important western education value when they arrive for their studies. Hammersley-Fletcher and Hanley (2016) examined the importance of critical thinking in HE in the UK with specific reference to international students. They suggested that there needs to be a shift in policy and practice with regard to how academics understand and promote critical thinking in academic work.

Apart from the key role of tutors in guiding international students and supporting them on both academic and sometimes pastoral levels, home students also play an 
important role in the academic journey of international students. Harrison and Peacock (2010) found that home students perceive the presence of international students as a threat to their academic success and group identity, specifically regarding academic learning in class and on the social front outside of the classroom. This can even lead to passive xenophobia among the majority (Harrison and Peacock, 2010).

The diversity of the student population, in which many UK universities take pride, has not led to diversity in interactions (Haines, 2007). This may be a threat to the longterm sustainability of the internationalisation of HE in the UK and beyond before it can become positive, meaningful, and non-threatening (Harrison and Peacock, 2010). Considering the transitional stages discussed earlier, this article investigates the potential issues and challenges confronting international students in the UK in their efforts to acquire academic knowledge and personal development. Are the processes of transitional adjustment and the ability to cope the same for all international students? Are the issues and challenges also the same across the board? How long does it take to get to the functioning stage? This research aims to investigate and answer to all these questions.

\section{Method}

Birkinshaw et al. (2011) argued that a multicultural group is a particularly complex phenomenon that should be studied and interpreted through qualitative studies. This holds true for the present study, which considers international students from different countries and cultural backgrounds. We used a multi-method qualitative approach. This approach encourages the use of multiple data sources (Saunders et al., 2012), which is essentially a mixture of semi-structured interviews and focus groups. A focus group is particularly useful for exploring in-depth, qualitative information in terms of the participants' thoughts, feelings, experiences, attitudes, and perceptions relating to the relevant concept or phenomenon (Sherraden, 2001).

Four universities in central London were chosen for this study. The selection of these universities was informed by the number and diversity of international students studying in them. The researcher paid careful attention to ethical considerations. The participants were informed of the purpose of the research and their unreserved right to end their participation at any stage of the study. Two datasets were carefully investigated, with specific attention given to the issues elucidated above.

The first dataset is formed of information taken from focus group interviews with 104 international students from 25 countries (Table 1). There were 13 rounds of focus group discussions, with eight participants in each session. Each session lasted about 75 minutes. Participants were purposively grouped according to their availability, and each session started by discussing the transitional period (Patton, 2002). The moderator (facilitator), however, ensured that the purpose of the exercise was not 
defeated (Silverman, 2006). Focus groups help in gaining diverse but congruent views, which interviews might not provide (Bryman, 2012). It is an 'information-rich' tool that is pertinent for achieving 'data saturation' (Krueger and Casey, 2000, p. 25). Focus groups further encourage participants to give genuine information unwittingly through its interactive mechanism, which increases validity (Bloor et al., 2001).

The second dataset is formed of information taken from in-depth semi-structured interviews with 21 lecturers (13 male, 8 female) with a vast experience in teaching in HE. Their age ranged between 36 and 56 years old and they reported an average of 12 years of working experience. The lecturers were interviewed individually at different times and places. The interviews lasted between 45 and 60 minutes. Semi-structured interviews permits flexibility and also enable the identification of the voice inflections, emotions, and body language of the interviewees (Saunders et al., 2012), especially when dealing with important issues (Okpu, 2016). As noted by Bryman (2012), the use of semi-structured interviews enables us to gather rich data that is vital to the achievement of the research's aim and objectives. As a two-way communication process, the data gleaned from this exercise gave us the platform to ask more questions based on the reactions of the participants concerning what can be regarded as a significant response.

Both datasets were digitally recorded and transcribed verbatim almost immediately after the interviews. Interview times and dates were confirmed via email, and all the participants were happy to participate in the study. Consent forms stating the purpose of the study and giving information regarding the benefits of the study were provided prior to beginning the interview sessions. The participants were required to complete the consent forms, thereby demonstrating their agreement to participate in the study.

All of the interviews were conducted in English. Eight respondents participated in each session of the focus group interviews. Semi-structured interviews were conducted on one-to-one basis with the participants. Furthermore, in order to ensure that the participants would speak freely, they were assured that their names, institutes, and comments would remain anonymous. Following the principle of induction, the interviews began with open questions, allowing the participants to share their subjective views on the relevant issues. Furthermore, in order to accommodate the participants' rich experiences and thoughts, the order of questions was maintained as flexible. The interviewers also remained open to new themes throughout the process, as recommended by Myers (2008). Data saturation was realised when emerging themes and motifs seemed recurrent (Glaser and Strauss, 1967) in the semi-structured and focus group interview sessions.

However, a brief session was held before every interview in order to gather the participants' background information. The main questions addressed to the focus 
group were (a) what are the issues and challenges confronting you in terms of your learning and development? (b) how do you cope with these issues and challenges? The main questions addressed to the lecturers in the semi-structured interviews were: (a) what do you think the issues and challenges confronting international students in terms of their learning and development are? (b) How do you think these issues and challenges can be overcome?

\section{Insert Table 1 about here}

A total of 104 students from 25 different countries took part in the focus group interviews, with their ages ranging between 17 and 32 years old. They were enrolled in foundation, undergraduate, and postgraduate programmes in their respective places of learning. The focus group participants were classified in no particular order, segregation or restriction. The open focus group membership ensures participant membership of each group is rich, diverse, and multicultural. This approach is a beneficial learning process for members of each group who by virtue of the diverse membership may learn from each other.

\section{Data Analysis}

The data analysis approach chosen for this study was an inductive approach (Glaser and Strauss, 1967). Using an 'open coding' technique (Strauss and Corbin, 1998), all the transcripts were carefully studied to identify the recurrent themes across them all. This process ensured that the themes were logically selected and that they were guided by inductive epistemology (Gerson and Horowitz, 2002). The coding was predominantly undertaken by the first author, with the emerging themes being frequently and intensely discussed with the second author during the entire process of data analysis.

After the coding process was finalised, the findings were crosschecked thoroughly by three of the authors again. An additional reliability check was undertaken by the fourth authors and an independent research assistant. This was done to ensure the consistency and reliability of the study. This check was then compared with the coding undertaken by the first author, based on the same set of transcripts. A satisfactory level of reliability was achieved. Subsequently, reports on the themes were prepared.

\section{Findings}

Across the dataset, the following major themes were found to be overwhelmingly recurrent: language/accent difficulties; impaired communication; and adjustment to the nature of the British education system (including the teaching style and the university system itself), culture, transport system, food, and weather. 


\section{Language/Accent Difficulties}

An overwhelming majority (92\%) of the participants mentioned, during the focus group interview, that they have struggled with the language barrier since they came to the UK to study. The participants complained about the regularity at which they are required to speak the English language and its impact on their learning. The following comments typify their shared experiences ('FGP' refers to 'focus group participant'):

I am struggling with the language. I have to speak it at all time....at school, on the bus, in the shop, almost everywhere. It's really difficult (FGP1).

Language, for me, is the main issue. Lessons, instructions, coursework, presentations, and exams are all given in the English language. I speak very little English, which reduces my understanding (FGP2).

Participants also commented on how their inability to speak and understand English fluently inhibits their participation in class activities:

My involvement in the class and learning activities is often curtailed by my inability to speak and understand the English language...or, I should say, I understand, but a little (FGP3).

Most of the time, I find it rather difficult to share experiences and opinions, or express myself in class, because I can't speak English properly...my roommates also have the same problem. This is our third month in the UK, and we are struggling to cope (FGP4).

In line with these findings, Peters (2010), Robertson et al. (2000), and Yarosha et al. (2018) argued that international students studying in foreign cultures are often confronted with linguistic challenges, which in many cases, negatively affect their academic performance.

As well as the language itself, many participants also commented on the difficulties involved in understanding the British accent. There are three categories of students here: (a) those who have difficulties understanding the English language, (b) those who have difficulties in understanding British accents, and (c) those who fall into both of the previous categories. The participants said:

I can say that I have a little understanding of the English language. However, since I arrived in England, it seems to me that the English 
they are speaking is different from the one I understand...I always struggle to understand the accents (FGP5).

My first three months were difficult. Understanding people at school, in shops, on the Tube, or on the bus was problematic...it's now better (FGP6).

Norman (2017) argued that the accent spoken by native English speakers could impact the communicative competence of international students. Other participants commented:

I did not understand what the teacher was saying. The accent was really difficult to understand. Same thing in other places like the church, shop...so, I was just staying indoors. That lasted for like two months. It is not perfect now, but it is better (FGP7).

I just arrived five weeks ago, and I am still struggling with the language and the accent. Everything seems like magic to me at the moment (FGP8).

The above statements represent the overwhelming majority (92\%) of the focus group participants' comments. Furthermore, the lecturers (who participated in the face-toface semi-structured interviews) also commented that language and accents remain a big issue for students, specifically international students from non-English speaking countries. One lecturer commented:

Students from English-speaking countries have no issue with the language. They may find the accent somewhat strange, but they are quickly adaptable. However, the story is different for students from non-English-speaking countries - the language and the accents are both issues (Participant A).

Another participant mentioned that students from francophone countries and some countries in Asia often struggle with understanding the English language and the British accent. She commented:

Students from francophone countries and some part of Asia found the English language and the British accent problematic. My concern, over the years, and this is different for different students, has been: how quickly can these students learn the English language and get used to the British accents? (Participant B).

Tiffany (2012) argued that international students may have problems when communicating with British locals due to various accents, which may affect the learning process of the students. Another participant said: 
I don't want to mention countries, but the majority of the students from Asia (not all of them) generally have problems with understanding the English language and the British accents (Participant D).

The majority of the lecturers believe that students should learn an appreciable degree of the English language and become accustomed to the British accents between six and eight weeks of their arrival, otherwise their learning process and the trajectory of their academic development is adversely affected. The following statements typify their shared views:

I believe that students should have a good understanding of the English language before arriving in the UK for their studies. However, if not, there is a window gap of between six and eight weeks for them to quickly learn and get used to it, otherwise they may have problems in their studies (Participant C).

Other participants commented:

I would say six weeks, because by that time, the lectures are already at an advanced stage, and if a student cannot cope at the six-week stage, then things may not work out well (Participant F).

For me, it is between six and seven weeks, and it is really important that students get on with the language and the accents within this period. From my experience, students who are unable to get on with the language and the accents within this time often either get withdrawn or have an extra year (Participant E).

The statements above represent the overwhelming majority (94\%) of the lecturers' comments on language and accents. Researchers have noted that language and accent barriers are the most common and overwhelmingly dominant problem confronting international students, which could give rise to academic difficulties and psychological anxiety (Campbell and Li, 2008; Ploner, 2018; Zhang and Mi, 2010;).

\section{Impaired Communication}

The majority of the participants (lecturers) commented on the issue of a general lack of communication skills as a result of difficulties in understanding the English language and the British accents. The following statements typify their shared views:

Difficulties in understanding the English language and the accents often limit the international students' (specifically those from Asia) communication and participation in classroom activities. They often seemed lost in the early stage (Participant V). 
Communication between the lecturers and the international students, and also between students from different cultures, for the first five weeks after their arrival or so, is often poor. This is because they usually find the conversational flow of the English language in the classroom quite difficult (Participant S).

The communication is one-way traffic, at least in the first four weeks of their arrival. Aside from the language and accent issues, they are not used to the British student-centred learning style. More so, most of the students from Asia (not all of them) are generally shy - they are not used to speaking in public...it sometimes takes some of them more than eight weeks to overcome most of these challenges (Participant K).

One participant clarified the issue more succinctly thus:

Communication for the first six weeks for them (international students) is poor for three reasons: (a) they struggle with the English language, (b) the accent is another massive issue for them, and (c) they often do not want to talk in the class for the fear of failure and criticism...they are not used to this system (Participant Q).

The issue of impaired communication between students and between students and lecturers is evident from the above comments. Communication, or miscommunication, remains a big problem for international students due to language and accent difficulties. Meanwhile, Park (2017) argued that a lack of adequate language proficiency for communication negatively affects the academic success of international students.

\section{The Education System}

All participants but three described the British education system as exceptional and strange in relation to their previous educational experiences in their respective countries. Getting used to the teaching style and the school system was problematic for them, specifically those who had just arrived. The following quotations typify the participants' focus group discussion:

The education system is new to me. It is just the opposite of the system in my country...I have never experienced it before. I think it's good, but I don't find it easy to adapt to (FGP12).

...discussion of case studies, group presentation, uploading coursework on Turnitin...strange, I find it difficult to adapt to and adopt this system (FGP 14). 
For me, the teaching style, online teaching materials and the method of assessment are weird. That is not what I am used to. Sometimes it seems to me like it is impossible to learn and get used to, but I think I am getting used to it. How long will it take? I honestly don't know (FGP 17).

I am a shy person, and I dislike talking in public. But now I have to engage in group discussions in class and group presentation, which are part of the summative assessment... it is difficult for me (FGP 19).

Some participants mentioned the school system as one of their problems with the UK education system. The majority of the participants specifically commented about commencement and finishing times.

The school system is also an issue for me...sometimes I will still be in school for lectures at 5pm. In my country, the time for study is between 10am and 3pm. I find it difficult to cope with the British system (FGP 21).

The lecturers also recounted their classroom experience with international students in terms of the nature of the British education system. Some tutors said:

A huge number of students came from a teacher-centred learning background, where the classroom environment, the teaching style, and the method of assessment are different. They learn the British education system as they move on; however, the quicker they learn the better for their learning and development (Participant Q).

The teaching style is a huge problem for them. A lot of them come from a background where they are not used to participating in classroom activities. Thus, getting them into the British education system is challenging (Participant R).

As noted by Scollon (1994), McLean and Ransom (2005), and Shaheen (2016), the majority of international students do not share the western idea of university system prior to their arrival. Therefore, quick adaptation to the system is fundamentally important to their academic success.

\section{The British Culture}

The majority of the participants commented on British culture, specifically the British transportation network, food, and weather.

\section{The London Transport Network System}

An overwhelming majority of the participants found the London transport network system difficult to understand and navigate at first, and many of them are still 
struggling, specifically in terms of the bus numbers and the London Underground network. Some participants commented:

The London transport system is complicated for me. The buses are numbered, and I have to start learning what bus number goes where. The Underground is even more difficult for me. I lost my way on several occasions, resulting in my lateness for lectures or sometimes just going back home (FGP27).

The transport system is a headache for me. The first six weeks of my arrival were difficult. I kept forgetting the bus number...I missed a couple of classes as a result (FGP 23).

I went on the wrong bus, which took me to an area that I did not know. I did not go to school that day because it was too late; I eventually found my way back home (FGP 25).

As much as I have tried to learn the London transport network system, four months on, I am still struggling with it. The only thing I know is that bus 68 takes me to school. Going out shopping or to socialising with friends has been difficult (FGP 31).

Another participant reflected:

I and a couple of my friends went out shopping, and the story was not a good one...because we got lost using the Underground. At that time, we had no idea where to go...we asked for directions, but the language barrier was an issue. At the end of the day, we came back home without shopping (FGP 29).

As indicated above, the participants find understanding the London transport system challenging. This has caused some of them to miss classes for weeks before getting used to it. Such attitude (missing classes) is symptomatic of culture shock, which many international student experience (Zhou et al., 2008). These findings also align with Newsome and Cooper's (2016) argument that individuals who encounter alien cultures often experience a sense of dislocation, which thrusts them into culture shock.

\section{The Food and the British Weather}

Some issues which pose a huge challenge to the participants are the British food and weather. The participants commented on the food, which the majority of them termed "cold food" and the weather, which they claimed made them sick and therefore sometimes unable to attend lectures. Some participants commented: 
Aside from the UK education system, the food and the weather are big issues for me. The Brits are used to frozen and cold food, and the weather too is very cold, which often makes me sick (FGP 37).

I missed a couple of classes last week due to illness...the food, and the weather are too cold for me (FGP 41).

It is my seventh week and I am still struggling with the weather...it is a sickly weather because it can be very cold in the morning, sunny in the afternoon, and really cold in the evening and at night. Sometimes, I cannot get out of my bed to go to school in the morning (FGP 43).

A participant summed up these issues as follows:

The first thing I battled with was the language and the accents. Even though I could speak some degree of English before I left China, I did not understand one bit of what people were saying when I arrived in the UK. They spoke too fast and the accents were difficult to understand. The transport system is tough, too...memorising bus numbers, and everywhere looks exactly the same to me. The education system is strange...participating in group discussion, group presentations, and the idea of Turnitin for assignments and coursework are completely alien to me, and indeed, my friends. The food and the weather are also problematic and made my first eight weeks massively difficult. I was struggling to get used to a wide range of things (FGP 39).

The above quotations further point to various difficulties that international students have in adjusting to a new environment. The difficulties are even worse if new students are unaware or falsely assume that the new society will operate like their home country (Zhou et al., 2008). Furthermore, the participants commented on the number of weeks it took them to actually get over the challenges. This number, however, varied from one group of students to another (see Table 2).

\section{Insert Table 2 about here}

Table 2, based on the findings of this study, shows the duration of the participants' involvement in each stage of the transition. Students from Asian countries, specifically those who are studying foundation courses, find the stormy stage of the transitional process rather challenging. They took between four and six weeks trying to find their ground in this stage before spending another four weeks in the acclimatisation stage.

Invariably, they started functioning as British students after ten weeks of their arrival. This is slightly different to undergraduate and postgraduate students, who spend between three and four weeks in the stormy stage, then the same period in the acclimatisation stage, before they start functioning after eight weeks. 
Students from Europe spend between three and four weeks in the stormy and acclimatisation stages before they start functioning after eight weeks, except for postgraduate students, who start to function after six weeks.

No participants from Africa on foundation courses participated in this study. However, participants from Africa on undergraduate and postgraduate courses spend three weeks each in the stormy and acclimatisation stages before they start to function after the sixth week. The lecturers thus consider that students should complete the stormy and acclimatisation stages and start functioning by the sixth week. One lecturer commented:

Students have different starts to their academic lives. Students from Asia, specifically China tend to have a slow start to their academic lives. However, it is crucial that students start to function properly at week six. This is important for their learning and development (Participant P).

Another lecturer commented on the implications of students' slow start to academic life:

For me, students should start functioning at week five. This is because serious academic activities would have begun by this time and if students are struggling to settle into the system at week five then their learning, development, grades, and overall success will be negatively affected. I have seen this happen over the years (Participant Z).

This participant said:

...I think its six weeks; otherwise, it will affect the whole learning and academic development process (Participant Y).

Pedagogical and cultural adaptations in higher education are essential requirements for the academic success of international students. However, the quicker they are able to adapt to the new culture and academic environment the better for their academic learning and development.

\section{Discussion}

As the globalisation of education brings students from all over the world to study in the UK, there is a growing need to investigate the transitional process of international students studying in the UK. An overwhelming majority (if not all) of the international students coming to study in the UK are expected to pass through different transitional stages from what they are used to in their respective native culture to the British social and academic system. The implication is that if the transitional adjustment (from stage 
one to the last stage) of international students is not properly and rapidly executed, achieving academic success may become difficult.

This article sets out to investigate the issues and challenges confronting international students in the UK in their efforts to acquire academic knowledge and personal development. The key issues highlighted from our data include language/accent difficulties and adjustment to the British education system and culture. These issues informed the creation of an empirical model, which conceptualised the international students' learning and development. The model further embedded an academic understanding of the process of the transitional adjustment of not just a particular group of students, but students from 25 different countries, thus fulfilling the global outlook of this article. The model includes three stages of transitional adjustment: the stormy stage, the acclimatisation stage, and the functioning stage.

The model is derivative of students' experience, a review of the extant literature (Brown and Holloway, 2008; Oberg, 1960; Torbiorn, 1994), and a call in the extant literature for further studies on students' transitions (Quan et al., 2016).

It is evident (Table 2) that students on foundation courses spend as much as six weeks in the stormy stage of their academic adventures in the UK. Meanwhile, undergraduate and postgraduate students spend as much as four weeks in this stage. The cultural values and students' prior academic experiences in their respective home countries are crucial for surviving a quick transition from this stage (Klineberg and Hull, 1979). Many students struggle in this stage because it is a stage at which everything is alien to them. However, this article posits that spending more than six weeks in the stormy stage may have a negative impact on student's learning and academic progress.

The acclimatisation stage appears to be easier than the stormy stage. Students at this stage have weathered the storm and are now getting used to the British academic and social climates. Students spend as much as three weeks in this stage. However, not all the students in the stormy stage will make it to this stage. The functioning stage is the ultimate stage, and students on foundation courses often reach this stage ten weeks after their arrival in the UK. The time involved in each stage varies according to the courses studied and the continents from which the students come (Table 2). This raises concerns about the implication of a slow transitional movement.

The empirical findings of this article highlight the numerous issues and challenges confronting international students in their bid to achieve academic success in the UK. An overwhelming majority of international students struggle with understanding the English language, which is further made difficult due to the high pace at which it is spoken and the unfamiliar accents. Park (2017) argued that a lack of adequate language proficiency for communication negatively affects the academic success of international students. Similarly, Yeh and Inose (2003) argued that a limited language 
proficiency could impact the social connectedness of international students and negatively impact their psychological wellbeing.

Additionally, there is a great deal of ineffective communication between students and lecturers and between students themselves in the stormy stage of the students' transition. This is attributed to language difficulties, difficulties in understanding the different British accents, a fear of failure, students' attitudes, and a fear of being criticised by the lecturers. This situation undoubtedly means that international students stay longer than necessary in a particular transitional stage (usually in the stormy stage), which is detrimental to effective learning and overall academic success. This is because a common classroom communicative feature, free-flow communication between the learners and the lecturer, is absent.

Furthermore, consistent with the research of Hyams-Ssekasi et al. (2014), this study found that the UK student-centred education system was strange to many international students. The majority of the participants are used to teacher-centred learning, in which students are supposed to be quiet and listen (See Nguyen et al., 2006). In this climate, students are mainly listeners, which is typical of most south-east Asian countries (Jin and Cortazzi, 2006; Kennedy, 2002; Nguyen et al., 2006). Meanwhile in student-centred learning, students are more active, and lecturers act as facilitators who promote students' independence and autonomy (Elmgren and Henriksson, 2014). Furthermore, the concept of plagiarism and interactive learning, inter alia, are outlandish to them, thus making the process of transitional adjustment slow and difficult.

The majority of the participants, specifically students from Asia, are not used to this system (student-centred learning style) and consequently found learning in this system somewhat difficult at first. It is essential to mention that the traditions and core values of the student-centred learning system are the hallmark of the British education system. The system helps students to develop critical, constructive, and creative minds and helps students to develop holistically (Braskamp et al., 2009).

Additionally, the British culture, specifically the transport system, food, and weather, is alien to the majority of international students. All of these issues and challenges make studying in the UK (especially for those studying foundation courses and first year undergraduates) a challenging experience for the international students. It is, however, important to highlight that these charms and challenges of British life are much the equivalent of the pleasures, attractions, and frustrations of any foreign travel. Future studies may reveal how such views experienced by these respondents change among those who remain in Britain after a couple of years.

However, this article has found that the speed of adaptation to British culture is essential in determining the students' academic success in the UK. Furthermore, the study has found that students should achieve the functioning stage at six weeks; otherwise, their academic success is negatively affected. International students' efforts 
to achieve academic success are not only frustrated by the abovementioned issues and challenges, but they also affect learning development.

\section{Conclusion}

This article has documented the issues and challenges confronting international students in their academic sojourn in the UK. The article, based on a review of the extant literature and empirical evidence, proposed a three-stage model to give a brighter insight into the international students' process of transitional adjustment. The findings show that international students have uneven potential to achieve the functioning stage. While some reach this stage six weeks after their arrival, it took some ten weeks, which could be detrimental to their overall academic success.

A robust mentoring programme and effective institutional support, which will accelerate students' progress from the stormy stage to the functioning stage, should be made available by HE institutions. Such support will enhance students' learning and development in the new global knowledge economy (Rizvi, 2007). While acknowledging institutional support, a key contribution of this study is the depiction of students' movements and the duration of the movement from the stormy stage to the functioning stage.

This will enable students (on a personal level) to be able to identify at what stage they are and the importance of getting to the functioning stage as quickly as possible. The assurance of effective learning and development and the provision of a culturally amenable learning approach, for international students, may be achieved if the necessary support is provided. Furthermore, a critical evaluation of the current academic discussions and practices in the UK is advisable.

Future research may undertake a comparative study on the process of the international students' transitional adjustment in different western countries comparing the issues and the challenges involved.

\section{Implications for Practice}

It is evident that the academic success of international students studying in the UK is predicated on their ability to be able to overcome various issues and challenges. International students primarily seek to obtain a qualification in addition to other life experiences and cultural assimilation. The students' parents, institutions, and the UK authorities (such as the Department of Education) have an important role in ensuring that the students achieve success.

With respect to academic performance, however, Morrison et al. (2005) examined several studies and found that international students performed better academically than the home student population. Based on these findings, the quality and the success of student learning and development depend on how successfully the students are able tackle the abovementioned issues and challenges. In other words, how quickly 
are they able to reach the functioning stage? It is proposed herein that six weeks is ideal for achieving the functioning stage in order to achieve academic success and the desired learning development. Students who are functioning at week five stand the chance of graduating with good results and vice-versa. The context (inside and outside of the institute) in which the learning occurs is essential (Entwistle et al., 2002).

Consequently, the challenge remains for various HEIs in the UK to devise a supportive welcome programme that will create an enabling environment in which smooth and successful learning and development is fostered. Additionally, UK HEIs could provide two to three-week pre-sessional programmes before the beginning of term, for which international students coming to study in the UK would have an option to register in order to help them 'acclimatise' and get used to the system before their main academic programmes commence.

Universities could also initiate a robust two-tier programme of pre and post arrival. The pre-arrival may involve formation of all-inclusive online training programme, including special videos to manage expectations. This will include information that are educational, informative in terms of cultural issues and potential challenges, and possible ways to deal with them. It will also include clarity about issues around wellbeing, where to get help and who to contact. Universities could also introduce a pre-arrival system that takes maximum advantage of social media networking where intending students could use the support of alumni as contacts and pen pals to help candidates before leaving their countries. These would increase their awareness and readiness for impending challenges.

Regarding the post-arrival, an integrative system such as a one-stop shop would be helpful where students could catch up on gaps around pre-arrival information and also have the opportunity to report problems and access relief. On arrival in the UK, staff members from same country or region, where available, could also be engaged to have drop in session with the students. This will go a long way in helping student to settle in and attain the functioning stage very quickly.

The findings of this research establish that UK universities and other HEIs must understand that the process of transitional adjustment is an important element of the support that they must offer to international students (Brown and Holloway, 2008; Ploner, 2018).

\section{References}

Al-Quhen, K. Y. (2012), "Cultural diversity in university requirements and among international students at Al al-Bay University in Jordan", European Journal of Social Science, Vol. 28, No. 4, pp. 489-501.

Andrade, M. S. (2006), "International students in English speaking universities", Journal of Research in International Education, Vol. 5, No. 2, pp. 131-154. 
Astin, A. W. (1993), What Matters in College: Four Critical Years Revisited, JosseyBass, San Francisco.

Association of American Colleges and Universities (2007), Global Learning for the New Global Century: Executive Summary with Findings from Employer Survey, Author; Washington, D.C.

Atack, P. (2018), Mental health concerns for 35\% int'l students. Available at https://thepienews.com/news/36-of-international-students-report-mental-healthissues/. Accessed 16 th $^{\text {th }}$ November 2018.

Barr, R. and Tagg, J. (1995), From Teaching to Learning: A new paradigm for undergraduate education. Change, Issue Nov/Dec, pp. 13-25.

Bennett, J. M. and Bennett, M. J. (2004), "Developing intercultural sensitivity: An integrative approach to global and domestic diversity", in Landis, D., Bennett, J. M. and Bennett, M. J. (Eds.), Handbook of intercultural training, Sage, Thousand Oaks, CA, pp. 147-165.

Biemans, H. and Van Mil, M. (2008), Learning styles of Chinese and Dutch students compared within the context of Dutch higher education in life sciences. The Journal of Agricultural Education and Extension, Vol. 14, No. 3, pp. 265-278.

Biggs, J. B. (2003), Teaching for quality learning at university: What the student does. Buckingham: The Society for Research into Higher Education \& Open University Press.

Biggs, J. B. (2001), “Enhancing learning: A matter of style or approach?” in Sternberg, R. J. and Zhang, L. (Eds.), Perspectives on thinking, learning, and cognitive styles, Lawrence Erlbaum Associates, Mahwah, NJ, pp. 73-102.

Birkinshaw, J., Brannen, M. Y. and Tung, R. L. (2011), "From a distance and generalizable to up close and grounded: Reclaiming a place for qualitative methods in international business research", Journal of International Business Studies, Vol. 42, No. 5, pp. 573-581.

Bloor, M., Frankland, J., Thomas, M. and Robson, K. (2001). Focus groups in social research. London: Sage.

Borrett, K. and Zysk, A. (2007). Relationships and friendships across cultures: Using "story telling" to engage new international students in conversations about friendships, relationships and sexuality. ISANA International Conference on Student success in international education (November 27-30) Stamford Grand, Adelaide, Australia. 
Boylan, H. R. (2002), "Graduate Attributes, why and how", Keynote paper. In: Proceedings of international lifelong learning conference, Yeppoon, QLD, Australia, 16-19 June. Rockhampton, QLD, Australia: Central Queensland University. Available at: http://hdl.cqu.edu.au/10018/3564 (Accessed November 2017).

Braskamp, L. A., Braskamp, D. C. and Merrill, K. (2009), “Assessing Progress in Global Learning and Development of Students with Education Abroad Experiences", Frontiers: The Interdisciplinary Journal of Study Abroad, Vol. 18, pp. 101-118.

British Council Report (2014), Integration of international students: A UK perspective. Available at https://www.britishcouncil.org/sites/default/files/oth-integration-reportseptember-14.pdf. Accessed 15 ${ }^{\text {th }}$ November 2018.

Brown, L. and Holloway, L. (2008), "The Initial Stage of the International Sojourn: Excitement or Culture Shock?" British Journal of Guidance and Counselling, Vol. 36, No. 1 , pp. 33-49.

Bryman, A. (2012). Social research methods. (4th edn). New York: Oxford University Press.

Cao, C., Zhu, C. and Meng, Q. (2018), “Chinese International Students' Coping Strategies, Social Support Resources in Response to Academic Stressors: Does Heritage Culture or Host Context Matter?" Current Psychology, pp. 1-11. Available at: https://doi-org.ezproxy.brunel.ac.uk/10.1007/s12144-018-9929-0. Accessed September 2018.

Campbell, J. and Li, M. (2008), “Asian students' voices: An empirical study of Asian students' learning experiences at a New Zealand University". Journal of Studies in International Education, Vol. 12, No. 4, pp. 375-396.

Deardorff, D. K. (2006), “Identification and assessment of intercultural competence as a student outcome of internationalization", Journal of Studies in International Education, Vol. 10, No. 3, pp. 241-266.

Deardorff, D. K. and Ararasatnam-Smith, L. (2017), Intercultural competence in international higher education: International approaches, assessment, application, Routledge, New York, NY.

Edmundson, A. (2007), Globalised e-learning cultural challenges. Information Science Publishing; London, Singapore.

Ejiofo, L. (2010), The experiences of international students in a predominantly white American university (2010). Educational Administration: Theses, Dissertations, and Student Research. Paper 22. http://digitalcommons.unl.edu/cehsedaddiss/22 
Elmgren, M. and Henriksson, A. S. (2014), Academic teaching. Lund: Student litteratur.

Entwistle, N. J. McCune, V. and Hounsell, J. (2002), Approaches to studying and perceptions of university teaching-learning environments: Concepts, measures, and preliminary findings. Occasional Report \#1, ETL Project. Edinburgh, UK: Universities of Edinburgh, Coventry, and Durham.

Eringa, K. and Huei-Ling, Y. (2009), Chinese students' perceptions of the intercultural competence of their tutors in PBL. In D. Gijbels and P. Daly (Eds.), Real learning opportunities at business school and beyond, 2, 17-37. Netherlands: Springer

Gerson, K. and Horowitz, R. (2002), "Observation and interviewing: Options and choices in qualitative research", in May, T. (Ed.), Qualitative research in action, Sage, London, pp. 199-224.

Glaser, B. G. and Strauss, A. (1967), The discovery grounded theory: strategies for qualitative inquiry, Aldin, Chicago.

Haines, D. (2007). "Crossing lines of difference: how college student analysis diversity", Intercultural Education, Vol. 18, No. 5, pp. 397-412.

Hammersley-Fletcher, L. and Hanley, C. (2016), “The use of critical thinking in higher education in relation to the international student: Shifting policy and practice", British Educational Research Journal, Vol. 42, No. 6, pp. 978-992.

Harrison, N. and Peacock, N. (2010), “Cultural distance, mindfulness and passive xenophobia: using integrated threat theory to explore home higher education students' perspectives on internationalisation at home", British Educational Research Journal, Vol. 36, No. 6, pp. 877-902.

Healey, N. M. (2017), “Beyond 'export education': aspiring to put students at the heart of a university's internationalisation strategy", Perspectives: Policy and Practice in Higher Education Vol. 21, No. 4, pp. 119-128.

Heffernan, T., Morrison, M., Basu, P. and Sweeney, A. (2010), "Cultural Differences, Learning Styles and Transnational Education", Journal of Higher Education Policy and Management, Vol.32, No. 1, pp. 27-39.

Hellstén, M. (2002), Internationalizing the curriculum. Internationalizing education in Asia-Pacific region: Critical reflections, critical times. $30^{\text {th }}$ Annual Conference of the Australian and New Zealand Comparative and International Education Society. Armidale, Australia.

Hockings, C. (2009), "Reaching the students that student-centred learning cannot reach", British Educational Research Journal, Vol. 35, No. 1, pp. 83-98. 
Hyams-Ssekasi, D., Mushibwe, P. and Caldwell, E. F. (2014), “International Education in the United Kingdom: The Challenges of the golden opportunity for black-African students", Sage Open Vol. 4, No. 4, pp. 1-13.

Idris, A., Ion, G. and Seery, A. (2019), "Peer learning in international higher education: the experience of international students in an Irish university", Irish Educational Studies, Vol. 38, No. 1, pp. 1-24.

Jin, L. and Cortazzi, M. (2006), "Changing practices in Chinese cultures of learning". Language, Culture and Curriculum, Vol. 19, No. 1, pp. 5-20.

Kegan, R. (1994), In Over Our Heads: The Mental Demands of Modern Life, Harvard University Press; Cambridge, MA.

Kember, D. (1997), "A reconceptualization of the research into university academics' conceptions of teaching", Learning and Instruction, Vol. 7, No. 3, pp. 255-275.

Kemmis, S. and Edwards-Groves, C. (2017), Understanding education: History, politics and practices. Springer; Singapore.

Kennedy, P. (2002), “Learning cultures and learning styles: Myth-understandings about adult (Hong Kong) Chinese learners". International journal of lifelong education, Vol. 21, No. 5, pp. 430-445.

King, R., Findlay, A. and Ahrens, J. (2010), International student mobility literature review. Report to HEFCE, co-funded by the British Council, UK National Agency for Erasmus, November. Available at: http://www.britishcouncil.org/hefce_bc_report2010.pdf. Accessed 30th January 2017. Kleinberg, O. and Hull, W. (1979), At a foreign university; an international study of adaptation and coping, Praeger, New York.

Knowles, M.S. (1980). The Modern Practice of Adult Education: From Pedagogy to Andragogy. 2nd edition, New York: Cambridge Books.

Knowles. M. (1989). The Making of an Adult Educator. San Francisco: Jossey-Bass.

Krueger, R. A. and Casey, M.A. (2000). Focus groups: A practical guide for applied research. Los Angeles.

Lago, C. (2003), Working with International Students: A Cross-Cultural Training Manual. Available at: http://institutions.ukcisa.org.uk/Info-for-universities-colleges-schools/Publications--research/resources/34/Working-with-International-Students-ACross-Cultural-Training-Manual-2003. Accessed $1^{\text {st }}$ February 2017. 
Lamberton, G. and Ashton-Hay, S. (2015), "Preparing Chinese international business students for the transition to undergraduate study in Australia", Journal of Research in International Education, Vol. 14, No. 2, pp. 155-171.

Li, G., Chen, W. and Duanmu, J. L. (2010), “Determinants of international students' academic performance: A comparison between Chinese and other international students", Journal of Studies in International Education, Vol. 14, No. 4, pp. 389-405.

Lillyman, S. and Bennett, C. (2014), "Providing a positive learning experience for international students studying at UK universities: A literature review", Journal of Research in International Education, Vol. 13, No. 1, pp. 63-75.

Lomer, S., Papatsiba, V. and Naido, R. (2016), "Constructing a national higher education brand for the UK: Positional competition and promised capitals", Studies in Higher Education, Vol. 43, No. 1, pp. 134-153.

Ma, J. and Wen, Q. (2018), “Understanding international students' in-class learning experiences in Chinese higher education institutions", Higher Education Research and Development, Vol.37, No. 6, pp. 1186-1200.

Major, E. M. (2005), “Co-national Support, Cultural Therapy, and the Adjustment of Asian Students to an English-Speaking University Culture", International Education Journal, Vol. 6, No. 1, pp. 84-95.

Mannan, M. (2007), "Student attrition and academic and social integration: Application of Tinto's model at the University of Papua New Guinea" Higher Education, Vol. 53, No. 2, pp. 147-165.

Marambe, K., Vermunt, J. D. and Boshuisen, H. (2012), "A cross-cultural comparison of student learning patterns in higher education." Higher Education, Vol. 64, No. 3, pp. 299-316.

Mascolo, M. F. (2009), "Beyond student-centered and teacher-centered pedagogy: Teaching and learning as guided participation." Pedagogy and the Human Sciences, Vol. 1, No. 1, pp. 3-27.

McLean, P. and Ransom, L. (2005) Building intercultural competencies. In J. Carroll \& J. Ryan (eds). Teaching International Students - Improving Learning for all (pp45-62). Oxon: Routledge.

Moore, P. and Hampton, G. (2015), "It's a bit of a generalisation, but...' participant perspectives on intercultural group assessment in higher education." Assessment and Evaluation in Higher Education, Vol. 40, No. 3, pp. 390-406. 
Morrison, J., Merrick, B., Higgs, S. and Le Métais, J. (2005), "Researching the performance of international students in the UK", Studies in Higher Education, Vol. 30, No. 3, pp. 327-337.

Mushibwe, C. P. (2009), What are the effects of cultural traditions on the education of women? The study of the Tumbuka people of Zambia (Doctoral thesis). University of Huddersfield. Retrieved from: http://eprints.hud.ac.uk/9090/. Accessed $27^{\text {th }}$ January 2017.

Musil, C. M. (2006), Assessing Global Learning: Matching good intentions with good practice. Washington, DC: Association of American Colleges and Universities.

Myers, M. D. (2008), Qualitative research in business and management, Sage, Thousand Oaks, CA.

Nada, C. and Araujo, H. C. (2017), “The multicultural experience of international students in Portugal: A narrative approach", Journal for Multicultural Education, Vol. 11, No. 3, pp. 176-188.

Newsome, L. K. and Cooper, P. (2016), “International students' cultural and social experiences in a British University: 'Such a hard life [it] is here'"'. Journal of International Students, Vol. 6, No. 1, pp. 195-215.

Nguyen, P. M., Terlouw, C. and Pilot, A. (2006), "Culturally appropriate pedagogy: The case of group learning in a Confucian Heritage Culture context". Intercultural Education, Vol. 17, No. 1, pp. 1-19.

Norman, J. (2017), Student's self-perceived English accent and its impact on their communicative competence and speaking confidence: An empirical study among students taking English 6 in upper-Secondary School. Available at https://www.divaportal.org/smash/get/diva2:1146855/FULLTEXT01.pdf.

Oberg, K. (1960), “Cultural Shock: Adjustment to New Cultural Environment." Practical Anthropology, Vol. 7, No. 4, pp. 177-182.

O'Neil, G. and McMahon, T. (2005), Student- centred learning: What does it mean for students and lecturers? Available at: http://eprints.teachingandlearning.ie/3345/1/O'Neill\%20and\%20McMahon\%202005.p df. Accessed $15^{\text {th }}$ January 2016.

Okpu, T. (2016), Employee voice and workers commitment in Nigerian workplace. Lap lambert Academic Publishing.

Pascarella, E. and Terenzini, P. (1991), How College Affects Students: Findings and Insights from Twenty Years of Research, Jossey-Bass, San Francisco. 
Patton, M.Q. (2002). Qualitative evaluation and research methods. (3rd ed.). Thousand Oaks, CA: Sage.

Peters, D.E. (2010), International Students and Academic Libraries: A Survey of Issues and Annotated Bibliography, Scarecrow Press, Lanham, MD.

Pike, A. and Harrison, J. (2011), "Crossing the FE/HE Divide: The Transition Experiences of Direct Entrants at Level 6", Journal of Further and Higher Education, Vol. 35, No. 1, pp. 55-67.

Ploner, J. (2018), “International students' transitions to UK Higher Education revisiting the concept and practice of academic hospitality", Journal of Research in International Education, Vol. 17, No. 2, pp. 164-178.

Quan, R., He, X. and Sloan, D. (2016), “Examining Chinese postgraduate students' academic adjustment in the UK higher education sector: a process-based stage model", Teaching in Higher Education, Vol. 21, No. 3, pp. 326-343.

Robertson, M., Line, M., Jones, S. and Thomas, S. (2000), "International students, learning environments and perceptions: A case study using the Delphi technique". Higher Education Research and Development, Vol. 19, No. 1, pp. 89-102.

Rodgers, R. F. (1990), "Recent theories and research underlying student development", in Creamer, D. G. and Associates, College student development: Theory and practice for the 1990s, American College Personnel Association, Alexandria, VA, pp. 27-79.

Rizvi, F. (2007), "Internationalization of curriculum: A critical perspective", in Hayden, M., Levy, J. and Thompson, J. (Eds.), The Sage handbook of international education, Sage, London, pp.390-440.

Ryan, J. (2011), “Teaching and learning for international students: Towards a transcultural approach", Teachers and Teaching, Vol. 17, No. 6, pp. 631-648.

Saunders, M., Lewis, P. and Thornhill, A. (2012). Research methods for business students. ( $8^{\text {th }}$ ed). Harlow: Pearson.

Schweisfurth, M. and Qing, G. (2009), “Exploring the experiences of international students in UK higher education: possibilities and limits of interculturality in university life", Interculturality and Higher Education, Vol. 20, No. 5, pp. 463-473.

Shaheen, N. (2016), “International students' critical thinking-related problem areas: UK university teachers' perspectives", Journal of Research in International Education, Vol. 15, No. 1,pp. 18-31.

Sharan, S. (1990), Cooperative learning: Theory and research, NY: Praeger, New York. 
Sherraden, M. (2001), "Asset building policy and programs for the poor", in Shapiro, T. and Wolff, E. N. (Eds.), Assets for the Poor: The Benefits of Spreading Asset Ownership, Russell Sage Foundation, New York, pp. 302-33.

Silverman, D. (2006), Interpreting qualitative data (3rd ed.). London: Sage.

Singaram, V. S., van der Vleuten, C. P. M., Stevens, F. and Dolmans, D. H. J. M. (2011). "For most of us Africans, we don't just speak": a qualitative investigation into collaborative heterogeneous PBL group learning." Advances in Health Sciences Education, Vol. 16, No. 3, pp. 297-310.

Sluss, D. M. and Ashforth, B. E. (2007), "Relational Identify and Identification: Defining Ourselves through Work Relationships", Academy of Management Review, Vol. 32, No. 1, pp. 9-32.

Smith, S. H. and Paracka, D. J. (2018), "Global learning is shared learning: Interdisciplinary intercultural competence at a comprehensive regional university", International Journal of Intercultural Relations, Vol. 63, pp. 17-26.

Strauss, A. and Corbin, J. (1998), Basics of Qualitative Research: Techniques and Procedures for Developing Grounded Theory (2nd ed.), Sage Publications, Thousand Oaks, London.

Tang, N. and Nollent, A. (2007), UK Transnational Education in China and Hong Kong. http://www.britishcouncil.org/eumd-information-research-tne-china-hk.htm. Accessed 17th June 2016.

Thanh, P. T. H. (2014), Implementing cross-cultural pedagogies: Cooperative learning at Confucian Heritage Cultures. Springer; Singapore, Heidelberg, New York, London.

Tiffany, P. G. (2012), An international student's guide to British accents. Available at https://istudyabroad.wordpress.com/2012/08/25/an-international-students-guide-tobritish-accents/. Accessed $24^{\text {th }}$ July 2016.

Tinto, V. (1987), Leaving College, University of Chicago Press, Chicago.

Torbiorn, I. (1994), “Dynamics of cross-cultural adaptation”, in Althen, G. (Ed.), Learning across cultures, NAFSA, New York, pp. 31-56.

UKCISA (2015), International students in the UK: Strengths, challenges and opportunities. A report on the UKCISA regional conferences 2014-201515. Available at http://www.ukcisa.org.uk/uploads/media/221/17664.pdf. Accessed $18^{\text {th }}$ November 2018. 
UKCISA (2017), Available at http://institutions.ukcisa.org.uk//Info-for-universitiescolleges--schools/Policy-research--statistics/Research--statistics/Internationalstudents-in-UK-HE/. Accessed on $18^{\text {th }}$ February 2017.

Wang, L. and Byram, M. (2011), "But when you are doing your exams it is the same as in China' - Chinese students adjusting to western approaches to teaching and learning", Cambridge Journal of Education, Vol. 41, No. 4, pp. 407-424.

Wettea, R. and Furneaux, C. (2018), "The academic discourse socialisation challenges and coping strategies of international graduate students entering English-medium universities", Journal of System, Vol. 78, pp. 186-200.

Wierstra, R. F. A., Kanselaar, G., Van der Linden, J. L., Lodewijks, H. G. L. C. and Vermunt, J. D. (2003), "The impact of the university context on European students' learning approaches and learning environment preferences." Higher Education, Vol. 45, No. 4, pp. 503-523.

Wu, W. and Hammond, M. (2011), "Challenges of University Adjustment in the UK: A Study of East Asian Master's Degree Students", Journal of Further and Higher Education, Vol. 35, No. 3, pp. 423-438.

Yarosha, M., Lukic D. and Santibáñez-Gruberc, R. (2018), “Intercultural competence for students in international joint master programmes", International Journal of Intercultural Relations, Vol. 66, pp. 52-72.

Yeh, C. J. and Inose, M. (2003), “International students' reported English fluency, social support satisfaction, and social connectedness as predictors of acculturative stress". Counselling Psychology Quarterly, Vol. 16, No. 1, pp. 15-28.

Zhang, Y. and Mi, Y. (2010), "Another look at the language difficulties of international students". Journal of Studies in International Education, Vol. 14, No. 4, pp. 371-388.

Zhou, Y., Jindal-Snape, D., Topping, K. and Todman, J. (2008), "Theoretical models of culture shock and adaptation in international students in higher education", Studies in Higher Education, Vol. 33, No. 1, pp. 63-75. 
Table 1 Focus Group Participants' Profile

\begin{tabular}{|c|c|c|c|c|c|c|}
\hline $\begin{array}{c}\text { Country of } \\
\text { origin }\end{array}$ & $\begin{array}{c}\text { No. of } \\
\text { participants }\end{array}$ & Age & $\begin{array}{c}\text { Pre-degree/ } \\
\text { Foundation }\end{array}$ & Undergraduate & Postgraduate & $\begin{array}{c}\text { Time in } \\
\text { UK }\end{array}$ \\
\hline China & 18 & $17-24$ & 9 & 7 & 2 & $1-3$ years \\
\hline Pakistan & 8 & $18-22$ & 4 & 4 & 0 & $1-2$ years \\
\hline Vietnam & 10 & $17-25$ & 5 & 3 & 2 & $1-2$ years \\
\hline Bangladesh & 5 & $18-23$ & 2 & 3 & 0 & $1-3$ years \\
\hline Turkey & 3 & $18-21$ & 2 & 1 & 0 & $1-2$ years \\
\hline Thailand & 4 & $17-23$ & 2 & 2 & 0 & $1-2$ years \\
\hline Saudi Arabia & 4 & $18-25$ & 1 & 2 & 1 & $1-2$ years \\
\hline Indonesia & 3 & $19-21$ & 1 & 2 & 0 & $1-2$ years \\
\hline Brunei & 4 & $17-20$ & 2 & 2 & 0 & $1-2$ years \\
\hline Libya & 4 & $18-21$ & 2 & 2 & 0 & $1-2$ years \\
\hline Uganda & 3 & $19-26$ & 0 & 3 & 1 & $1-2$ years \\
\hline Nigeria & 3 & $20-32$ & 0 & 1 & 2 & $1-2$ years \\
\hline Hong Kong & 3 & $17-20$ & 1 & 2 & 0 & $1-2$ years \\
\hline Russia & 4 & $17-21$ & 2 & 2 & 0 & $1-2$ years \\
\hline Ghana & 3 & $19-31$ & 0 & 2 & 1 & $1-2$ years \\
\hline Italy & 3 & $18-20$ & 2 & 1 & 0 & $1-2$ years \\
\hline Japan & 3 & $18-21$ & 0 & 3 & 0 & $1-3$ years \\
\hline Uzbekistan & 2 & $18-21$ & 2 & 0 & 0 & 1 year \\
\hline Sweden & 2 & $17-19$ & 1 & 1 & 0 & 1 year \\
\hline Burma & 2 & $18-20$ & 1 & 1 & 0 & 1 year \\
\hline France & 3 & $19-21$ & 1 & 2 & 0 & $1-2$ years \\
\hline Germany & 3 & $18-21$ & 1 & 2 & 0 & $1-2$ years \\
\hline Afghanistan & 2 & $18-20$ & 1 & 1 & 0 & 1 year \\
\hline Morocco & 2 & $18-19$ & 2 & 0 & 0 & 1 years \\
\hline Algeria & 3 & $18-22$ & 1 & 2 & 0 & $1-2$ years \\
\hline Total & $\mathbf{1 0 4}$ & & & & & \\
\hline
\end{tabular}

Table 2 Duration In Transition Stages

\begin{tabular}{|c|c|c|c|}
\hline \multicolumn{1}{|c|}{ Students } & \multicolumn{1}{l}{} \\
\hline Asian Students (68) & Stormy Stage & Acclimatisation Stage & Functioning Stage \\
\hline Foundation & $4-6$ weeks & $3-4$ weeks & After 10 weeks \\
\hline Undergraduate & $3-4$ weeks & $3-4$ weeks & After 8 weeks \\
\hline Postgraduate & $3-4$ weeks & $3-4$ weeks & After 8 weeks \\
\hline & & & \\
\hline European Students (18) & Stormy Stage & Acclimatisation Stage & Functioning Stage \\
\hline Foundation & $3-4$ weeks & $3-4$ weeks & After 8 weeks \\
\hline Undergraduate & $3-4$ weeks & $3-4$ weeks & After 8 weeks \\
\hline Postgraduate & 3 weeks & 3 weeks & After 8 weeks \\
\hline & & & \\
\hline African Students (18) & Stormy Stage & Acclimatisation Stage & Functioning Stage \\
\hline Foundation & - & - & - \\
\hline Undergraduate & 3 weeks & 3 weeks & After 6 weeks \\
\hline Postgraduate & 3 weeks & 3 weeks & After 6 weeks \\
\hline
\end{tabular}


Figure 1 International Students Studying in the UK

\section{International student numbers by UK nation 2016-17}

\begin{tabular}{llll}
\hline Country & $\begin{array}{l}\text { Total EU } \\
\text { students (not } \\
\text { incl UK) }\end{array}$ & $\begin{array}{l}\text { Total non- } \\
\text { EU } \\
\text { students }\end{array}$ & $\begin{array}{l}\text { Total } \\
\text { international } \\
\text { students }\end{array}$ \\
\hline England & 104,875 & 258,710 & 363,585 \\
\hline Scotland & 21,245 & 31,045 & 52,290 \\
\hline Wales & 6,235 & 14,970 & 21,206 \\
\hline $\begin{array}{l}\text { Northern } \\
\text { Ireland }\end{array}$ & 2,480 & 2,810 & 5,290 \\
\hline UK & 134,835 & 307,540 & 442,375 \\
\hline
\end{tabular}

Source: Higher Education Statistical Agency (HESA)

\section{Figure 2 Three stage Scaffolding model}

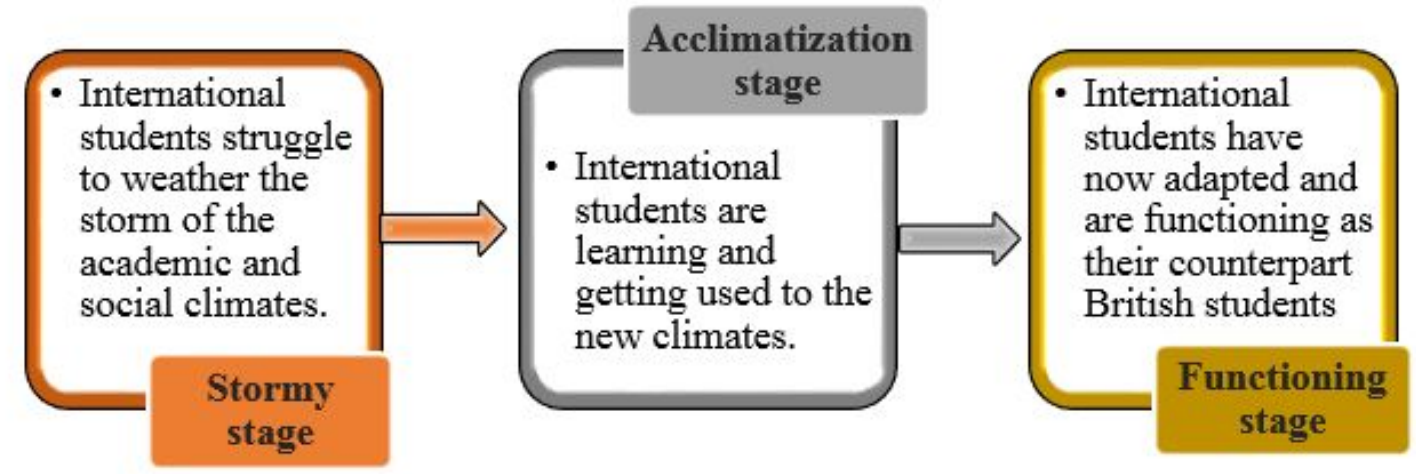

